Annals of Plant and Soil Research 23(1): 112-115 (2021)

https://doi.org/10.47815/apsr.2021.10040

\title{
Influence of plant densities and fertility levels on growth and yield of chickpea (CicerarietinumL.) genotypes
}

\author{
GURINDER SINGH, MOHINDER LAL AND PRADEEP KUMAR \\ Department of Agriculture, G.S.S.D.G.S. Khalsa College, Patiala, Punjab, India-147001 \\ Received: November, 2020; Revised accepted: December, 2020
}

\begin{abstract}
A field experiment was conducted at Research and Advanced Studies, Dhablan, Department of Agriculture, Khalsa College, Patiala during rabiseason 2019-20 to find out the influence of plant densities and fertility levels on growth and yield of chickpea (Cicer arietinum L.) genotypes. The experiment was conducted in factorial randomized block design and replicated thrice. The experiment consisted of two genotypes (PBG 7 and GPF 2), two planting densities and two fertility levels. The results revealed that the genotype PBG 7 recorded significantly highestgrain yield (18.01 $\left.\mathrm{q} \mathrm{ha}^{-1}\right)$ as compared to genotype GPF2 (16.62 q ha $\left.{ }^{-1}\right)$. The growth parameters were also higher with genotype PBG 7 followed by GPF 2 . The density of $30 \times 10 \mathrm{~cm}$ recorded. The highest grain and straw yield (17.47 and $22.51 \mathrm{q} \mathrm{ha}^{-1}$ )as compared to $45 \times 10 \mathrm{~cm}$ spacing (16.74 and $\left.18.53 \mathrm{q} \mathrm{ha}^{-1}\right)$. However, yield attributes like pods plant ${ }^{-1}$, grain yield plant ${ }^{-1}$ and harvest index were higher with wider planting density $(45 \times 10 \mathrm{~cm})$. Higher fertility level $\left(N_{30} P_{60} K_{30} S_{20} \mathrm{~kg} \mathrm{ha}^{-1}\right)$ produced highest grain yield $\left(17.88 \mathrm{q} \mathrm{ha} \mathrm{a}^{-1}\right)$ as compared to low fertility levels $\left(16.75 \mathrm{q} \mathrm{ha} \mathrm{h}^{-1}\right)$. The growth and yield parameters followed the similar trend. The chickpea genotype PBG 7 showed better response to closer planting density and higher fertility level.
\end{abstract}

Keywords: Chickpea, genotype, plant density, fertility level

\section{INTRODUCTION}

Chickpea (Cicer arietinum L.) is the second most important pulse crop after pigeon pea in the world of human diet and other use. It is an important winter season pulse crop in India grown as a dry pulse crop. Chickpea contributes $47 \%$ of the total pulse production and about $40 \%$ of total pulse growing area in the country. In India, Madhya Pradesh ranks first in area and production of chickpea followed by Rajasthan.It contains all the essential amino acids except $S$ containing amino acids.Being a leguminous crop, chickpea improves soil fertility by fixing atmospheric nitrogen in the roots through the phenomena of symbiosis. Application of nitrogen fertilization improves the seed yield, seed protein and amino acids. Among all the factors of productivity, application of phosphorus contributes directly to yield of the chickpea and also plays an important role in physiological functions of the plant. However, potassium acts as a catalyst in activating several enzymes as incorporation of amino acids in protein, synthesis of peptide bonds etc. Potassium enhance the resistance in plants against different abiotic factors like drought, heat, frost and various abiotic factors like disease caused by fungi, nematode and other microorganism (Ahmed et al. 2015). Also sulphur is an essential element in forming proteins, enzymes, vitamins and chlorophyll in plants. It is crucial in nodule development and efficient nitrogen fixation in legumes. It is an important factor in determining the nutritional quality of foods. The optimum density with proper plant geometry is one of the important characters which can be manipulated to attain the maximum production from per unit land area (Prasad et al. 2012). Proper geometry is dependent on variety of chickpea, its growth habit and agro climatic condition. Plant population also depends upon the environmental conditions under which the chickpea is grown (Kumar et al. 2018). Selection of cultivar andits adaptation on a particular environment is also an important factor. Old and degenerated cultivars due to poor yield potential and other drawbacks like shattering habits, late maturity, poor response to fertilizer, susceptible to diseases and insect pest results lower yield productivity as compared to the improved cultivars. Keeping these facts in view, the present study was initiated using chickpea as test crop. 


\section{MATERIALS AND METHODS}

The field experiment was conducted at Research and Advanced Studies, Dhablan, Department of Agriculture, G.S.S.D.G.S. Khalsa College, Patiala during rabiseason of 2019-20. The experiment was conducted in factorial randomized block design. The soil of experimental field contained $262 \mathrm{~kg} \mathrm{ha}^{-1}$ available $\mathrm{N}, 22 \mathrm{~kg} \mathrm{ha}^{-1}$ available $\mathrm{P}$ and $129 \mathrm{~kg} \mathrm{ha}^{-1}$ available K. Soil of experimental field was clayey in texture having soil $\mathrm{pH} 7.3$ and $5.2 \mathrm{~g} \mathrm{~kg}^{-1}$ organic carbon. The experimental site is situated at $30^{\circ} 19^{\prime}$ North latitude and $76^{\circ} 24^{\prime}$ East longitude at an altitude of 250 metre above the mean sea level. The experiment consisted of two genotypes (PBG 7 and GPF 2), two planting densities $(30 \times 10$ and $45 \times 10 \mathrm{~cm})$ and two fertility levels $\left(20 \mathrm{~kg} \mathrm{~N}+40 \mathrm{~kg} \mathrm{P}_{2} \mathrm{O}_{5}+20 \mathrm{~kg} \mathrm{~K}_{2} \mathrm{O}\right.$ $+20 \mathrm{~kg} \mathrm{~S}$ and $30 \mathrm{~kg} \mathrm{~N}+60 \mathrm{~kg} \mathrm{P} \mathrm{O}_{5}+30 \mathrm{~kg} \mathrm{~K} 2 \mathrm{O}$ $+20 \mathrm{~kg} \mathrm{Sha}^{-1}$ ) were replicated three times. The different doses of fertilizer as per treatment were applied in the form of urea, single superphosphate and murateof potash, respectively at the time of sowing. The crop was sown on 23 October 2019. Cultural operations carried out in the experimental field were done bymanually. Thinning and gap filling was done on 4 December 2019, hand weedings were done on 26 December 2019, 26 January 2020, 5 March 2020. Harvesting of crop was done on 2 April, 2020 and threshing was done on 8 April, 2020. The observations recorded were growth parameters like plant height, dry weight,branches plant ${ }^{-1}$ at maturity; development parameters like days to flowering initiation, days to $50 \%$ flowering and days to maturity; yield attributes and yield parameters like pods plant ${ }^{-1}$, grains pod $^{-1}$, grain yield, straw yield, biological yield, test weight and harvest index. The data were statistically analysed as per procedure given by Gomez and Gomez (1984).

\section{RESULTS AND DISCUSSION}

\section{Genotypes}

Genotype PBG 7 differed significantly in dry weight and branches plant ${ }^{-1}$ at maturity as compared to genotype GPF 2 (Table1).PBG 7 produced significantlyhighest dry weight (378.7) gand more branches plant ${ }^{-1}$ at maturity (6.43) as compared to GPF 2.This might be due to superior varietal characters and genetic potential of variety PBG 7.Plant height and developmental parameters did not differ significantlybetween both genotypes of chickpea(Table 1).Similar results were observed by Goyal et al. (2010). Grain yield and harvest indexwere observed significantly higher with genotype PBG 7due to efficient utilization of resources by variety PBG 7 (Table 2). PBG 7 produced significantly highest grain yield (18.01 q ha ${ }^{-1}$ ) as compared to GPF 2 . Lower grain yield (16.60 q ha-1) was produced by GPF 2.Similar results were reported by Nawangeet al. (2018). Test weight, straw yield and biological yield did not produce significant results with both genotypes of chickpea.

Table1: Influence of genotype, Plant density and Fertility levels on growth and development parameters of chickpea

\begin{tabular}{|c|c|c|c|c|c|c|}
\hline Treatments & $\begin{array}{l}\text { Plant height } \\
\text { (cm) }\end{array}$ & $\begin{array}{l}\text { Dry weight } \\
\text { (g) } \mathrm{m}^{-1} \text { row } \\
\text { length }\end{array}$ & $\begin{array}{l}\text { Branches } \\
\text { plant }^{-1} \text { at } \\
\text { maturity }\end{array}$ & $\begin{array}{c}\text { Days to } \\
\text { flowering } \\
\text { initiation }\end{array}$ & $\begin{array}{c}\text { Days to } \\
50 \% \\
\text { flowering }\end{array}$ & $\begin{array}{l}\text { Days to } \\
\text { maturity }\end{array}$ \\
\hline \multicolumn{7}{|l|}{ Genotype } \\
\hline PBG 7 & 63.3 & 378.7 & 6.43 & 105.5 & 112.8 & 155.2 \\
\hline GPF 2 & 63.6 & 334.0 & 5.62 & 105.7 & 112.6 & 155.6 \\
\hline $\mathrm{SE}(\mathrm{m})$ & 0.34 & 11.6 & 0.22 & 0.31 & 0.32 & 0.36 \\
\hline C.D. & NS & 35.2 & 0.66 & NS & NS & NS \\
\hline \multicolumn{7}{|l|}{ Plant density } \\
\hline $30 \times 10 \mathrm{~cm}$ & 63.3 & 333.0 & 5.22 & 105.1 & 112.4 & 154.9 \\
\hline $45 \times 10 \mathrm{~cm}$ & 63.7 & 380.8 & 6.03 & 106.1 & 112.7 & 155.8 \\
\hline $\mathrm{SE}(\mathrm{m})$ & 0.34 & 11.6 & 0.22 & 0.31 & 0.32 & 0.36 \\
\hline C.D. & NS & 35.2 & 0.66 & 0.96 & NS & NS \\
\hline \multicolumn{7}{|l|}{ Fertility levels ( $\mathrm{ka} \mathrm{ha}^{-1}$ ) } \\
\hline $\mathrm{N}_{30} \mathrm{P}_{60} \mathrm{~K}_{30} \mathrm{~S}_{20} \mathrm{~kg} \mathrm{ha}^{-1}$ & 62.5 & 330.4 & 4.85 & 106.0 & 112.5 & 155.5 \\
\hline $\mathrm{N}_{20} \mathrm{P}_{40} \mathrm{~K}_{20} \mathrm{~S}_{20} \mathrm{~kg} \mathrm{ha}^{-1}$ & 64.5 & 382.4 & 6.72 & 105.2 & 112.9 & 154.8 \\
\hline $\mathrm{SE}(\mathrm{m})$ & 0.34 & 11.6 & 0.22 & 0.31 & 0.32 & 0.36 \\
\hline C.D. & 1.03 & 35.2 & 0.66 & NS & NS & NS \\
\hline
\end{tabular}




\section{Plant density}

Dry weight, branches plant $^{-1}$ at maturity and days to flowering initiation increased with decrease of plant density (Table 1). A plant density of $45 \times 10 \mathrm{~cm}$ resulted significant higher dry weight, branches plant ${ }^{-1}$ at maturity and days to flowering initiation as compared to plant density of $30 \times 10 \mathrm{~cm}$. The number of pods plant ${ }^{1}$, grain yield plant $^{-1}$ and harvest index were observed more with plant density of $45 \times 10 \mathrm{~cm}$ (Table 2). The number of pods plant ${ }^{-1}$ decreased with increase in plant density while total number of pods per unit land area increased with increase in plant density. Contrary to this, grain yield, straw yield and biological yield weresignificantly higher with plant density of $30 \times$ $10 \mathrm{~cm}$. This might be due to grain yield increases with increasing the total number of pods per unit land area at closer planting in chickpea. Hence, straw and biological yield were significantly higher with plant density of $30 \times 10$ $\mathrm{cm}$. Similar results was also reported by Girma (2013) and Nawangeet al (2018). The results clearly suggest that individual plant under lower plant population density performed better than plant under higher plant population density. The improvement in yield attributing characters under lower plant population was not sufficient enough to compensate the loss of density for higher seed yield.

Table 2: Influence of genotype, Plant density and Fertility levels on yield and yield attributeng characters of chickpea

\begin{tabular}{|c|c|c|c|c|c|c|c|}
\hline Treatments & $\begin{array}{l}\text { Pods } \\
\text { plant }^{-1}\end{array}$ & $\begin{array}{l}\text { Grains } \\
\text { pod }^{-1}\end{array}$ & $\begin{array}{c}\text { Test } \\
\text { weight } \\
\text { (g) }\end{array}$ & $\begin{array}{l}\text { Grain } \\
\text { yield } \\
\left(\mathrm{q} \mathrm{ha} \mathrm{ha}^{-1}\right)\end{array}$ & $\begin{array}{c}\text { Straw } \\
\text { yield } \\
\left(q \text { ha }^{-1}\right)\end{array}$ & $\begin{array}{l}\text { Biological } \\
\text { yield } \\
\left(\mathrm{q} \mathrm{ha}^{-1}\right)\end{array}$ & $\begin{array}{c}\text { Harvest } \\
\text { index } \\
(\%)\end{array}$ \\
\hline \multicolumn{8}{|l|}{ Genotype } \\
\hline PBG 7 & 42.4 & 2.04 & 136.7 & 18.01 & 19.98 & 37.99 & 47.4 \\
\hline GPF 2 & 44.6 & 2.32 & 137.4 & 16.62 & 21.06 & 37.68 & 44.4 \\
\hline $\mathrm{SE}(\mathrm{m})$ & 0.64 & 0.08 & 0.49 & 0.14 & 0.43 & 0.48 & 0.53 \\
\hline C.D. & 1.94 & 0.25 & NS & 0.42 & NS & NS & 1.60 \\
\hline \multicolumn{8}{|l|}{ Plant density } \\
\hline $30 \times 10 \mathrm{~cm}$ & 42.0 & 2.15 & 136.9 & 17.47 & 22.51 & 39.98 & 43.6 \\
\hline $45 \times 10 \mathrm{~cm}$ & 44.9 & 2.26 & 138.0 & 16.74 & 18.53 & 35.27 & 47.4 \\
\hline $\mathrm{SE}(\mathrm{m})$ & 0.64 & 0.08 & 0.49 & 0.14 & 0.43 & 0.48 & 0.53 \\
\hline $\begin{array}{l}\text { C.D. } \\
\text { Fertility levels }\left(\mathrm{kg} \mathrm{ha}^{-1}\right)\end{array}$ & 1.94 & NS & NS & 0.42 & 1.31 & 1.46 & 1.60 \\
\hline $\mathrm{N}_{30} \mathrm{P}_{60} \mathrm{~K}_{30} \mathrm{~S}_{20} \mathrm{~kg} \mathrm{ha}^{-1}$ & 42.1 & 2.06 & 138.0 & 16.75 & 20.85 & 37.60 & 44.7 \\
\hline $\mathrm{N}_{20} \mathrm{P}_{40} \mathrm{~K}_{20} \mathrm{~S}_{20} \mathrm{~kg} \mathrm{ha}^{-1}$ & 45.9 & 2.35 & 136.9 & 17.88 & 20.19 & 38.07 & 47.1 \\
\hline $\mathrm{SE}(\mathrm{m})$ & 0.64 & 0.08 & 0.49 & 0.14 & 0.43 & 0.48 & 0.53 \\
\hline C.D. & 1.94 & 0.25 & NS & 0.42 & NS & NS & 1.60 \\
\hline
\end{tabular}

\section{Soil fertility}

Application of $30 \mathrm{~kg} \mathrm{~N}+60 \mathrm{~kg} \mathrm{P}_{2} \mathrm{O}_{5}+30$ $\mathrm{kg} \mathrm{K}_{2} \mathrm{O}+20 \mathrm{~kg} \mathrm{~S} \mathrm{ha}^{-1}$ recorded significantly higher growth as compared to lower fertility level

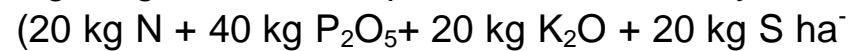
$\left.{ }^{1}\right)$. The higher fertility level significantly produced more plant height, dry weight and number ofbranches plant $^{-1}$ at maturity. The growth parameters were significantly improved due to morechlorophyll formation by additional amount of nutrients, which ultimately increased the food material for the plant to stimulate growth of plant.
Similar results were also reported by Goyal et al (2010) and Kumar et al. (2018). The higher fertility level recorded significantly more number of pods plant ${ }^{-1}$, number of grains pod $^{-1}$, grain yield and harvest index (Table2). The possible reason for increase in yield parameters could be that higher fertilization dose improving dry matter production in turn might have resulted in greater synthesis of photosynthesis contributing to increase in number of pods plant ${ }^{-1}$. The more number of pods plant ${ }^{-1}$ finally led to higher grain yield. Similar data was observed by Goyal et al (2010) and Odyuo and Sharma (2020). 


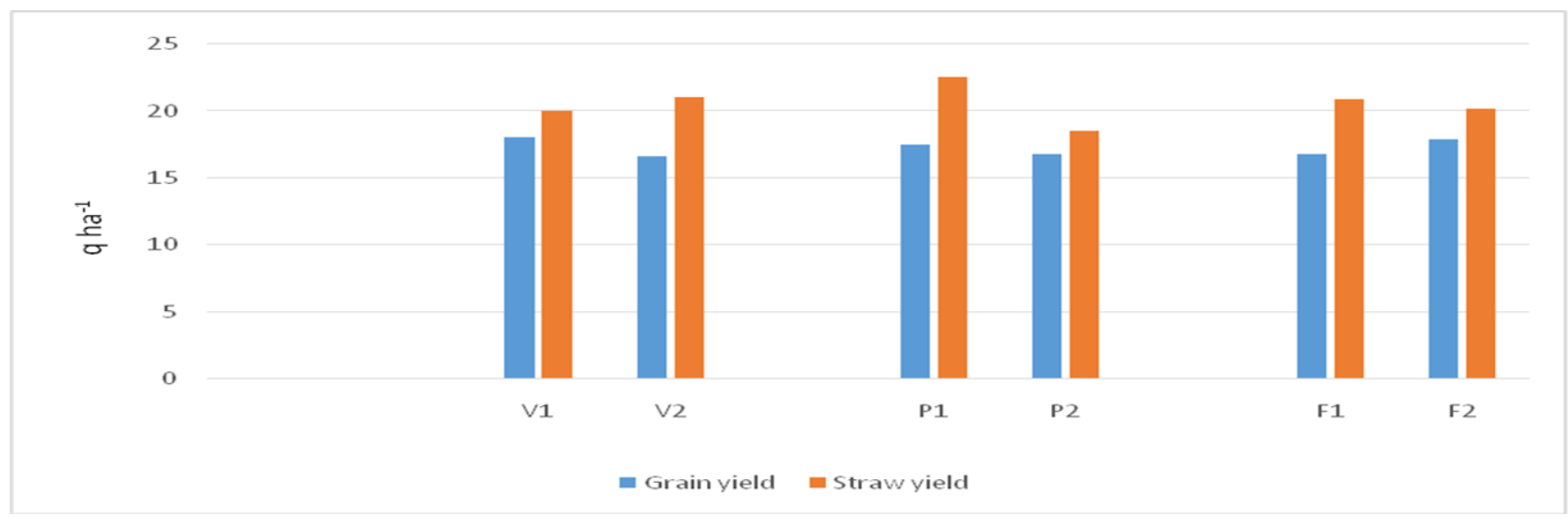

Fig 1: Effect of genotyps, plant density and fertility levels on yield of chickpea

It may be concluded from the results that the genotype PBG 7 gave higher growth, development and grain yield as compared to genotype GPF 2.Planting density of $30 \times 10 \mathrm{~cm}$ proved more beneficial for maximum production of genotypes of chickpea.Higher fertility level

\section{REFERENCES}

Ahmed, A.G., Mohamed, M.H, Hassanein, M.S, Zaki, N.M, Habbasha, S.F.E, Tawifk, M.M. and Mohamed, M.F.(2015) Effect of water regime and potassium fertilization on productivity of two chickpea (Cicer arietinum L.) cultivars. International Journal of Chemtech Research 8(4):1509-19.

Dhima, K,,Vasilakoglou, I,, Stefanou, S. and Eleftherohorinos, I. (2015) Effect of cultivar, irrigation and nitrogen fertilization on chickpea (Cicerarietinum L.) productivity. Agricultural Sciences 6:1187-94.

Girma, A. (2013) Response of chickpea to different planting methods and planting densities under dryland condition. Basic Research Journal of Agricultural Science 2(9):186-90.

G omez, K.A. and Gomez, A.A. (1984) Statistical procedures for Agricultural Research.Second Edition.John Willy \& Sons, New York.

Goyal, S., Verma, H.D, and Nawange, D.D. (2010) Studies on growth and yield of kabuli chickpea (Cicerarietinum L.) genotypes under different plant densities and fertility levels. Legume Research 33(3):221-23.

Kumar, H, Yadav, B.S., Singh, R, Yadav, D.D,, Chahal, V.P,, Yadav, R. and Yadav, O.S. was found suitable for highest yield of chickpea.Thus, chickpea crop fertilized with 30 $\mathrm{kg} \mathrm{N}+60 \mathrm{~kg} \mathrm{P}_{2} \mathrm{O}_{5}+30 \mathrm{~kg} \mathrm{~K}_{2} \mathrm{O}+20 \mathrm{~kg} \mathrm{~S} \mathrm{ha}^{-1}$ and gram at spacing of $30 \times 10 \mathrm{~cm}$ produced higher yield of grain and straw.

(2018) Effect of potassium levels on performance of chickpea (Cicerarietinum L.) under different genotypes. International Journal of Chemical Studies 6(6):1675-77.

Kumar, S., Khande, R.S,, Sonboir, H.L, Pande, N. and Bhambri, M.C. (2018) Effect of sowing time, spacing and nipping on growth and yield of chickpea (Cicerarietinum L.) under irrigated conditions. International Journal of Chemical Studies 6(1):1218-22.

Nawange, D.D., Verma, H.D. and Verma, H. (2018) Growth and yield performance of kabuli chickpea (Cicerarietinum L.) genotype under different planting geometry and fertility levels in Vindhya Plateau Region. International Journal of Agriculture Sciences 10(5):5291-93.

Prasad, D., Bangarwa, A.S,, Kumar, S. and Ram A. (2012) Effect of sowing dates and plant population on chickpea (Cicerarietinum L.) genotypes. Indian Journal of Agronomy 57(2):206-08.

Odyuo, Z. R. and Sharma, Y.K., (2020) Response of green gram (Vignaradiata) to fertility levels in acid soil of Nagaland. Annals of Plant and Soil Research 22(3): 296-300. 